\title{
17TH-CENTURY MANCHU (QING) RECORDS AS SOURCES OF MONGOLIAN HISTORY*
}

\author{
BYOUNGHAK CHO-SUNG HOON JEH-KISUN KIM
}

\author{
College of Liberal Arts, Gachon University, Seongnamdae-ro 1342, Sujeong-gu, \\ Seongnam-si, Korea, \#13120 \\ e-mail: bhcho@gachon.ac.kr \\ Hankuk University of Foreign Studies, Imun-ro 107, Dongdaemun-gu, Seoul, Korea, \#02450 \\ e-mail: hufsbart@gmail.com \\ Hankuk University of Foreign Studies, Imunro 107, Dongdaemun-gu, Seoul, Korea, \#02450 \\ e-mail: monvic12@hufs.ac.kr
}

\begin{abstract}
This paper makes an attempt to call attention and point to the importance of Manchu historical records, but at the same time warns against the pitfalls of uncritical utilisation of these historical sources (the possibility of falsification and the fabrication of historical material). The authors focus on volume 20 of the 親征平定朔漠方略 Qinzhengpingdingshuo-mofanglüe (Beye dailame wargi amargi babe necihiyeme toktobuha bodogon i bithe. orici debtelin) written in Manchu. This Manchu historical document is of prime importance in the historical enquiry of the period. It gives a clear picture of the military strategy of the time and provides accurate facts concerning the exact names of persons and places, the system of administration, wartime munitions mobilisation, and much more.
\end{abstract}

Key words: Beye dailame wargi amargi babe necihiyeme toktobuha bodogon i bithe. orici debtelin, Secret Palace Memorials of the KangXi Period, Manchu historical records, strategy books, Manchu and Mongol scripts, Tangan, Qing Dynasty, Galdan, KangXi.

\section{Introduction}

Borjigidai Oyunbilig of China, in his recently published book dealing with problems of 17th-century Mongolian history, amply demonstrated the importance of the surviving historical records and presented some of the problems related to the utilisation of this source material. Actually, the book is a collection of fourteen studies written at different times and occasions) (Borjigidai Oyunbilig 2009). ${ }^{1}$ He has addressed the R226).

* This work was supported by the Gachon University research fund of 2013 (GCU-2013-

${ }^{1}$ The following themes are tackled in his book: dichotomy of historical materials and its significance; a Manchu document from Emperor Kangxi's 2nd Galdan expedition; Mongo Asut village; nomadic land of the 'Chahar Country' in the early Qing Dynasty, etc. 
importance of Tangan documents in his research, as well as the importance of Qing Dynasty Manchuria and Mongolia Tangan and Mongolian historical research. ${ }^{2}$ Additionally, he has introduced new Tangan documents that were sent and received by government agencies in the course of their work.

The present response clearly resonates within the larger context of Borjigidai Oyunbilig's primary research arguments. Nonetheless, the aim of this manuscript is to purely express the importance and problems of Manchu historical records in Qing Dynasty Mongol history, which are evident from reading the Manchu script: specific examples can be found in the Qinzhengpingdingshuomofanglüe (Writing of the strategy that guided the military and conquered the Northwestern region) (hereinafter Chinese books are unified in the Bibliography as pinyin) ${ }^{3}$. The texts of the 'strategy books' are those that deal with wartime strategies, as mentioned above, and which had been written since the time of Emperor KangXi. Aside from Qinzhengpingdingshuomofanglüe, the categories also include 淸朝藩部要略稿本 Qingchaoofanpuyaolüegaoben, 皇朝藩部要略 Huangchaofanpuyaolüe and 平定準噶爾方略 PingdingJungarfanglüe, etc. and these generally tend to praise the appropriateness and achievements of the Emperor's allotted span of life from the Qing's point of view. Favouring the Manchu script, the strategy book Qinzhengpingdingshuomofanglüe has been selected because it has attained special value as a historical text recorded in Manchu script.

On 1st of August 1696, not long after Emperor KangXi returned to Beijing following his Jungar Mongol expedition, he ordered three government ministers and Hanlimyuan to compile a history of the military expeditions to Galdan. The Chinesescript version became entitled 親征平定朔漠方略 Qinzhengpingdingshuomofanglüe. The collection was compiled from 1696 to 1710, and contains a total of 102 books, including 51 books in both Manchu and Chinese script (out of these books there were 48 main books, in addition to the Emperor's preface, the Emperor's summary and the list). The preface written by the Emperor in 1708 was later attached. The Manchu and Chinese woodblock-printed books were published together, and the preface explains that the Chinese script is selectively adapted and translated (Perdue 2005, pp. 586587).

\section{The Importance and Problems of Manchu Historical Records}

In what follows, the contents of the Manchu-script version of the Qinzhengpingdingshuomofanglüe (volume 20, pp. 21-25) will be given (The Chinese-character version can be found in the same volume 20, pp. 15-17).

\footnotetext{
${ }^{2}$ Byounghak Cho wrote a similar paper in the journal of the Korean Association for Mongolian Studies (Cho 2011).

${ }^{3}$ Manchu script: beye dailame wargi amargi babe necihiyeme toktobuha bodogon i bithe.
} 


\subsection{The Importance of Manchu Historical Records}

\subsubsection{The Concreteness of Truth}

Xin chou (辛丑, 'White Cow') day, well digging on the West road army's road to the expedition $^{4}$

(1) High General Fiyanggū received a command to send someone outside Karun to dig a well. To that, Fiyanggū reported: On February 12th, I went to Yang ho province and met lieutenant general Adi. Road officer Adi said to me: 'There are two roads from Guigwacheng (Huhu Hoton) to Karun. If you advance from Munai you can arrive in Karun in 20 days, or if you follow Kundulen, you can arrive in Karun in 19 days. Both roads have clear streams and fountains so there is no need to dig a well. On the road from Karun to Godoli Balhasun, there is a total of 13 deduns (站) and at every post station, there are wells in more than 10 locations. On the road to Galbai cagan kuten there are 17 deduns and at each dedun there are more than 10 wells. Orders were given to dig all these wells deep again, some wells are 5, 6 cheoks (Chinese foot 尺) deep and some are 2, 3 cheoks. Water can be drawn from the deep wells but at the shallow ones there are sand and mud mixed in with the water, so you probably can't draw any water'... The Emperor said, according to Adi, places that have been dug will be deep and other places have not been dug up yet. Because well digging is related to the army's date of departure, quickly send lama Šangnan dorji and lieutenant general Ayusi to Fiyanggū by horse. Send people so that they can start digging the wells as soon as they receive word and allow the large military force to depart as planned. Šangnan dorji knows both Manchu and Mongol scripts and can receive and send all documents, have him stay at the camp with Fiyanggū and take care of things together.

\subsubsection{Possibility of Tracking Names of People and Places and Administrative System}

(2) Ren yin (王寅, 'Black Tiger') day, an Imperial order for imperator Fiyanggū.

The Emperor commanded Fiyanggū: I have already discussed the advance of the army with several subjects and sent a letter to you. I hear that Gendun daicing beile has advanced to Cishib province, a part of honggorai. I am worried that your two military units will misunderstand Kalka as Oirat so describe this in detail to Ananda to let him know. Also, after you have passed Onggin give a good guide to

${ }^{4}$ Beye dailame wargi amargi babe necihiyeme toktobuha bodogon i bithe. orici debtelin, pp. 21-25. "šahūn ihan inenggi. hesei amba jiyanggiyūn be, fiyanggū be, niyalma takūrafi karun i tule hūcin fetebu sehe....erebe mini dolo ambula jobošome, cohome galai arafi, hahilame wasimbuha sehe." 
Šangnan dorji and report back where you are coming from, which roads you will pass and the date to the Emperor's camp. These two tasks, however, are not urgent, but forward this command to Adi.

\subsubsection{Possibility of Tracking Mobilisation of Wartime Goods}

(3) Further commands given to Fiyanggū: According to reports by Zhongbingguan G'angtiyaoyuwan (康調元), there is talk that the mules and rice Shan-Xi siyūnfu promised to assist with the expedition have not yet arrived. Looking at this, the large army's departure date is approaching but it does not mean that there is no time to spare. (So do not hasten or become impatient.) The link between rice and livestock is very important; assign the front and back to the generals and have them direct them. Your road to expedition is long and food transportation will be more difficult than it is for the Middle road army. If the food rations do not last, soldiers in your two military units will suffer. I am deeply worried and thus I send this special hand-written imperial order urgently.

Even 300 years later, reading passages from the twenty volumes of Qinzhengpingdingshuomofanglüe allows us to feel the events vividly. (1) is about the order to dig wells on an expedition. These communications tell us that efforts were made to secure drinking water before mobilising troops and that Šangnan dorji's proficiency in both Manchu and Mongol script was utilised for administrative convenience. (2) is about orders how not to mistake allied forces for enemy forces, and for the use of guides to prevent geographic confusion, while (3) shows the orders were not to be swayed by rumours, to manage food and livestock, and to recognise the importance of transporting goods. The content of these specific and detailed archives do not appear in 清實錄 準噶爾史料摘編 (Qingshilu Jungarshiliaozhaibian - “Jungarshiliao" Editing Team 1987), which ties together excerpts from Qingshilu related to Jungar. From the documents in the front and back: 'Article in February, Golden Pig (己亥) year' (Jungar's Tsewang rabtan sent messenger Nangsu - Qingshilu, Vol. 171, bottom of p. 6-top of p. 8) and 'Article in February Blue Dragon (甲辰) year' (the background and legitimacy of Emperor KangXi's first expedition - Qingshilu. Vol. 171, bottom of p. 9-top of p. 10). It can be deduced that Qinzhengpingdingshuomofanglüe was used as an original historical document in the compilation of Qingshilu. As similar 'strategy books', such as 淸朝藩部要略 Qingchaofanpuyaolüe and 平定準噶爾 方略 PingdingJungarfanglüe, do not contain any trace of this content, we can say with some certainty that Manchu Qinzhengpingdingshuomofanglüe is a very valuable document for the historical record. Thus, this text possesses a concreteness and reality of the actual events at that time.

Borjigidai Oyunbilig comparative essay (2009), 'Emperor KangXi’s Second Expedition', from Qinzhengpingdingshuomofanglüe, with Secret Palace Memorials of the KangXi Period has exposed the fabricated portions and additionally the fact that the Chinese script of Qinzhengpingdingshuomofanglüe has more deviations from the original than the Manchu script. History books from the government, such as Qin- 
zhengpingdingshuomofanglüe or 清實錄 Qingshilu have the unfortunate problems of reliability, i.e. of being modified or manipulated according to the wishes of the Emperor or dynasty court. However, many items were immune to such modification, such as normal logistical situations, mobilisation and organisation of forces, military commands, rewards and punishments, weapons and formal military inspections. Similarly, the content of the quotations regarding the above issues between the Emperor and the commanding officers, as well as other matters relating to everyday business, were things that could be enough to hear the sound of breath and the conversations between the Emperor and his servants. These were things that were practical and related to their particular sites. Through these documents, the political, economic, social, cultural, and general situations of the time can be inferred. This is the advantage and importance of the Manchu script Qinzhengpingdingshuomofanglüe as a primary historical source.

\subsection{Problems of the Manchu Historical Records}

The reason for emphasising the importance of the Manchu historical record is that it is chronologically closest to the events of the time, and it is thus the primary historical material containing the most detailed records. Of course, Manchu historical records are not without problems. No record is devoid of the subjectivity of its recorder. The Manchu historical records that have survived are strategy books and authentic records that were published by the state, and consequently their records are, to some extent, biased in favour of the Emperor.

In the original Manchu language Qinzhengpingdingshuomofanglüe, original text materials were selected for specific purposes and their compilers likewise had similar objectives. Selection sought to praise the Emperor's achievements by providing evidence of heavenly support for the plans of the Emperor and his foresight. For example, in order to show that Emperor KangXi actually saw through Galdan's false offer from the beginning, and that he indeed actually waited the proposed period of 70 days, the discussion between Emperor KangXi and Gereiguying, along with the relevant dates, were changed (Perdue 2005, pp. 590-591). The problems inherent in these records of 'selecting desired direction of historical records' and 'modification of the truth by changing dates' are thus evident.

\subsubsection{The Possibility of Falsification (Falsification of the Date of Galdan's Death)}

Fiyanggū's report regarding Galdan's death can be observed in the Qingshilu. ${ }^{5}$ On 9th of April, 36th year of KangXi (1697), when Fiyanggū arrived at a place called Sair

5 淸實錄 (Qingshilu) Vol. 5, ShengZushilu (2), zhonghuashujuchuban, ShengZushilu No. 183, From April to May, 36th year of KangXi, p. 956.

"When a ship carrying the Emperor reached Bugutu on Blue Mouse Day, Muwon imperator bo Fiyanggu reported: When we arrived at Sairbalhasun on April 9th, 36th year of KangXi, Danjila et al. of Oirat sent 9 people including Cikirjaisang to tell us that: On leap month March 13, Galdan 
balhasun, Danjila's nine envoys came to Fiyanggū and showed intentions of surrendering: it is recorded that on leap March 13th, Galdan took drugs and committed suicide. His body was burned and his daughter Juncahai took the ashes and stayed at a place called Baya endur with 300 families waiting for the Emperor's order. The content of Cikir's (Danjila's messenger) report three days later corroborates that of Fiyanggū's report. ${ }^{6}$

However, Secret Palace Memorials of the KangXi Period simply state: 'On March 13th, Galdan arrived at a place called Aca amtatai and died'. This was changed to 'died on leap March 13th, suicide from drugs' in the Qingshilu. Danjila's messenger, Cikir, clearly reported 'died on March 13th'. Emperor KangXi met with Cikir jaisang on April 18th and asked him in person, and he answered that he was certain Galdan died of suicide by drugs. Either several people schemed to have him take the drug, or he himself took it. ${ }^{7}$ After the face-to-face encounter with Cikir, the theory that Galdan committed suicide by taking drug became accepted as fact. This was recorded in the Qingshilu and when future historians wrote about Jungar Mongol, this was quoted without reservation. In fact, however, there is no evidence that 'on leap March 13th, Galdan committed suicide by drug use'.

\subsubsection{The Possibility of the Fabrication of Historical Material}

Another similar point of suspicion can be found in a letter Emperor KangXi sent to the Crown Prince. Unlike the ' 14 letters', Emperor KangXi said it was useless, a fact that listening to Galdan's thoughts and voice is very meaningful. They can be heard by looking at the part of Manchu complete translation of the Secret Palace Memorials of the KangXi Period, volume 8, document 120, in which Emperor KangXi made lamas translate Galdan's letter probably written in Tibetan into Manchu:

'No matter what happens, I respect and admire the Dalai Lama and I pray to meet you soon. Please give me the order with good words and definition for the date month and year when you can meet!"9

came to Acaamtatai and killed himself with a drug. Danjila, noyan Gelung, and Danjila's son-in-law Lasilun surrenderred with the remains of Galdan and a total of 300 households including Galdan's daughter Juncahai etc. Danjila's horses are exhausted and have no food to eat so they are waiting for the emperor's command while staying in a place called Bayaendur."

${ }^{6}$ Qingshilu, Vol. 5, ShengZushilu(2), zhonghuashujuchuban, ShengZushilu No. 183, From April to May, 36th year of KangXi, p. 957.

${ }^{7}$ Secret Palace Memorials of the KangXi Period, Vol. 9, printed by National Palace Museum. Published in June, 66th year of the Republic of China (hereinafter unified as KangXizouzhe) Document, 207: "juwan jakūn de muna be duleke manggi cikir jaisang, isinjiha, ... dere de kimcime fonjici, g'aldan i bucehengge okto omifi beyebe arahange yargiyan, eici geren acafi oktoloho, ini cisui okto omiha babe, ...". On 18th, passing Muna, Cikir jaisang said. I questioned him in detail face to face and then was sure that Galdan killed himself by taking medicine. Otherwise several people co-operated to let Galdan drink medicine or Galden himself drank medicine.

${ }^{8}$ KangXizouzhe Vol. 8, Document 106, Arrived on November 23rd, 35th year of KangXi, '14 letters deprived by Qing army, sent by Galdan to the Dalai Lama of Tibet and Diva etc.'.

${ }^{9}$ KangXizouzhe Vol. 8, Document 120, p. 547. "ajige niyalma bi ai ocibe dalai lama be ginggulere kundulere. gūniha amba baita be mutebufi dalai lama be hūdun bahafi acara jalin hūturi 
From this passage we know that Galdan relied on the Dalai Lama until the end, and until the time he wrote this letter (September 1696) he did not know of the death of the fifth Dalai Lama. Okada Hidehiro’s 康熙の手紙 Letter from Emperor $K a n g X i$ said that rumours according to which the fifth Dalai Lama had died nine years before were already widespread among the Jungar people who fought in the Joo mod battle (June 1696) (Okada 2013, p. 92). ${ }^{10}$ Does this mean that Galdan did not know about the rumours of 'Dalai Lama's death' that had previously circulated? From the contents of this letter, it can be assumed that Galdan did not know of the Dalai Lama's death until at least September, when this letter was written and obviously that was why he was still capable of writing such a letter. This is somehow inconsistent with the physical evidence and suggests the likelihood of fabrication.

\section{The Need for Comparative Studies on Historical Records}

If you closely inspect Danjila's expedition in the Secret Palace Memorials of the KangXi Period (volume 8, p. 546, document 120), the text reads: 'we fought with 1500 soldiers who were guarding the rice and killed several people and brought back various livestock'. This event could be seen as the food extortion incident at Onggin river which involved reserve rice stored for the Qing Army. It was to be eaten on their return, and which occurred after the Qing army attacked Galdan's army in Bayan ulan (1st military expedition of KangXi). There are two ways to understand this 'Danjila's expedition'. First, as it is stated in the original letter: 'Many people said to dispatch armies towards the enemy, so with Danjila as the leader, many soldiers were sent'. If it was a battle to revenge the military loss at Joo mod, the fight with ' 1500 soldiers guarding the rice' might refer to another rice storage.

Based on this evidence, the date when Galdan wrote this letter was September $3 \mathrm{rd},{ }^{11}$ but, according to Jungarshilüe, the incident occured on September 6th, ${ }^{12}$ and in Okada Hidehiro's Letter from Emperor KangXi the date is stated as October 4th ${ }^{13}$,

baime jalbarimbi. ere songkoi mutebure aniya biya inenggi erin be sain hese sain gisun i getukeleme hese wasimbureo."

${ }^{10}$ However, it was 1682 that the Dalai Lama V died actually, which was 15 years earlier.

${ }^{11}$ Secret Palace Memorials of the KangXi Period, 8th collection, p. 591 and the letter to Cecen Daicing of p. 593, the date when the letter was written as 'fulgiyan singgeri aniya. uyun biyai ice ilan ... (Year of Red Rat - 1696, 35th year of KangXi September 3rd)'.

${ }^{12}$ Page 106 of Jungarshilüesays that Danjila tried to seize the Qing Army food warehouse in Onggin on September 6th, citing of Zhuangjifa QingdaiJungarshiliaozhaibian, Emperor's words on September 28th, 35th year of KangXi, "On September 6th, 1696, Galdan's man, Danjila led some soldiers to seize the Qing Army food warehouse in Onggin".

${ }^{13}$ Secret Palace Memorials of the KangXi Period, Vol. 8, pp. 293-294. Chinese translation document 199. "September 20, 35th year of KangXi: goroki be dahabure amba jiyanggiyūn hiya kadalara dorgi amban be i bithe. tulergi golo be dasara jurgan de unggihe. hese hwang taidz de wasimbuha. sikini sere jalin. elhe taifin i gūsin sui ci aniya uyun biyai orin i honin erinde, ūlet i ayusi gebungge niyalma dahame jifi alarangge bi ajir budune ci. danjila be dahame amasi benderefi onggin i bele bisire bade baime genehede ere biyai ice ninggun i erde onggin de bisire cooha jurara be 
thus suggesting the event occurred after Galdan had written the letter. Therefore, the Danjila's expedition could not have been the Onggin river event. However, according to p. 176 of Letter from Emperor KangXi the situation is described in the following manner: 'Galdan's soldiers left Tamir river on July 26th and headed southward towards Onggin river. There is a food dump left by the Qing army at the Onggin river. If it were to fall in the enemy's hands, it would have been very difficult to solve the Galdan problem. The Emperor was to go out to the frontline himself and to lead the strategy. This passage shows that the army had already 'left the Tamir river on July 26th and headed southward towards the Onggin river', and suggests that this was one of the main backgrounds to the 2nd military expedition of the Emperor. From Galdan's letter, we can see that Danjila's expedition to obtain the rice store room at Onggin river had already started on July 26th, and it is possible that the fight with 1500 soldiers guarding the rice can be understood as Danjila's 'Onggin River food extortion case', which had already occurred before September 3rd.

This example shows the importance of a comparative study of historical records of the 'Onggin rice extortion event'. The date of this event can only be deduced from various materials.

\section{Conclusion}

Because 'strategy books' such as Qinzhengpingdingshuomofanglüe were published to praise the achievements of the Emperor and pass his greatness on to future generations, there may be factors that affect the selection and falsification of original historical records. Thus, it is necessary to maintain an objective viewpoint and analyse historical records by comparing and contrasting them with original historical records. 'Galdan's letter' in the Secret Palace Memorials of the KangXi Period (Vol. 8, document 120) comes closest to the original historical record. Thus, original historical records such as the Secret Palace Memorials of the KangXi Period are the most reliable sources. Dramatised and selected records in this vein can be called Qinzhengpingdingshuomofanglüe.

This paper investigated the correspondence between the Emperor and the officers-in-command, as reflected in the Qinzhengpingdingshuomofanglüe, Qingshilu and the Secret Palace Memorials of the KangXi Period (Vol. 9, document 206). On the example of 'the date of Galdan's death' the authors tried to highlight the importance of these historical documents and to point to the difficulties having emerged in their research.

Manchu historical records, such as the Qinzhengpingdingshuomofanglüe, are very important for researching the history of Mongolia in the Qing Dynasty, as they give detailed references to the events that occurred shortly before. However, not all of these records can be trusted. Since the 'strategy books' were closely related to the Emperor's personal dignity, and the influence on future generations was constantly

sabufi. be daldalafi majige yalubuha manggi. danjila meni ūlet sebe gaifi. morin aciha be duriki seme afanaha de nukte be fiyanjilame yabure cooha poo miyoocan sindame alime gaifi afame. ..." 
kept in mind, there are sections that were skilfully manipulated. Thus, by comparing texts with the original historical records, researchers are obliged to point out these manipulated parts and reproduce the actual facts of the past as they had really occurred.

\section{References}

Bao, Wenhan (1997): 清朝藩部要略稿本 Qingchao Fanbu Yaolüe Gaoben [Summary on a remote region in the period of the Qing Dynasty]. Heirongjiang-jiaoyu-chubanshe.

Borjigidai, Oyunbilig (2009): Manchu Document Left in Emperor KangXi's 2nd Galdan Expedition. In: 17世紀蒙古史論考 [A study on 17th-century Mongolian history], pp. 88-157.

Cho, Byounghak (2011): A Study of Qing Dynasty Manchuria Mongolia Tangan and Mongolian History. 몽골학 [Mongolian studies] Vol. 31, pp. 41-61.

Fuheng (ed.): 平定準噶爾方略 [PingdingJungarfanglüe] [Strategy for quelling Jungar]. Xizangshehuikexueyuan-xizangxuehanwenwenxian-bianjishi.

Hummel, Arthur W. (1943): Eminent Chinese of the Ch'ing Period. Washington, United States Government Printing Office.

“Jungarshiliao” Editing Team (1987): 清實錄 準噶爾史料摘編 《Qingshilu》Jungarshiliaozhaibian [Collection of historical materials on Jungar from the Annals of the Qing Dynasty]. Xinjiang-renmin-chubanshe.

Manchu version, Wenda (ed.) (1709): Beye dailame wargi amargi babe necihiyeme toktobuha bodogon $i$ bithe [Strategy for quelling remote regions, directly led by Emperor]. Vol. 20, pp. $21-25$.

National Palace Museum (2000): 親征平定朔漠方略 Qinzhengpingdingshuo-mofanglüe, Chinese character version. Hainan-chubanshe, Vol. 1, pp. 222-223.

National Palace Museum Shih Lin, Taipei Republic of China (1977a): 宮中檔康熙朝奏摺 [Secret Palace Memorials of the KangXi Period], Special Series No. 8, pp. 293-294, 591-592.

National Palace Museum Shih Lin, Taipei Republic of China (1977b): 宮中檔康熙朝奏摺 [Secret Palace Memorials of the KangXi Period], Special Series No. 9, p. 40.

Okada, Hidehiro (2013): 康熙の手紙 [Letter from Emperor KangXi]. Deungwon Bookstore.

Perdue, Peter C. (2005): China Marches West - The Qing Conquest of Central Eurasia. Translated by Gong, Won-guk (2012): 중국의 서진 [China marches West]. Seoul, Publishing Company Ghil. 